\title{
Patriotismo e
}

\section{gênero na tradição}

\author{
do pensamento
}

\section{político moderno:}

\section{uma genealogia}

"A língua é minha pátria,

E eu não tenho pátria: tenho mátria,

Eu quero frátria"

(Caetano Veloso).

JOSÉ EISENBERG

é professor de Ciência

Política do luperj e autor

de As Missões Jesuíticas

e o Pensamento Político Moderno (Ed. UFMG) e

A Democracia depois do

Liberalismo (Relume-

Dumará).
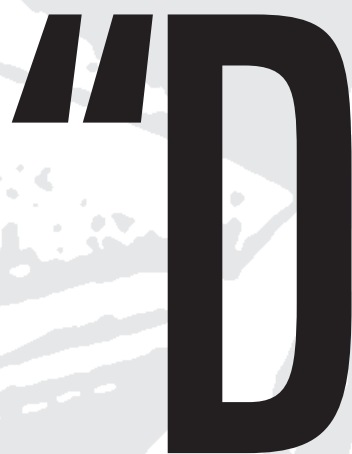

os filhos deste solo és mãe gentil, pátria

amada Brasil." A estrofe final da letra de

Joaquim Osório Duque Estrada para o

nosso Hino Nacional denuncia um curioso paradoxo de nossa tradição republicana, astutamente retorcido por Caetano Veloso na canção "Língua": clamamos uma pátria como mãe - seria ela, portanto, uma mátria? - em que a associação clássica entre paternidade e amor à terra natal é substituída por 


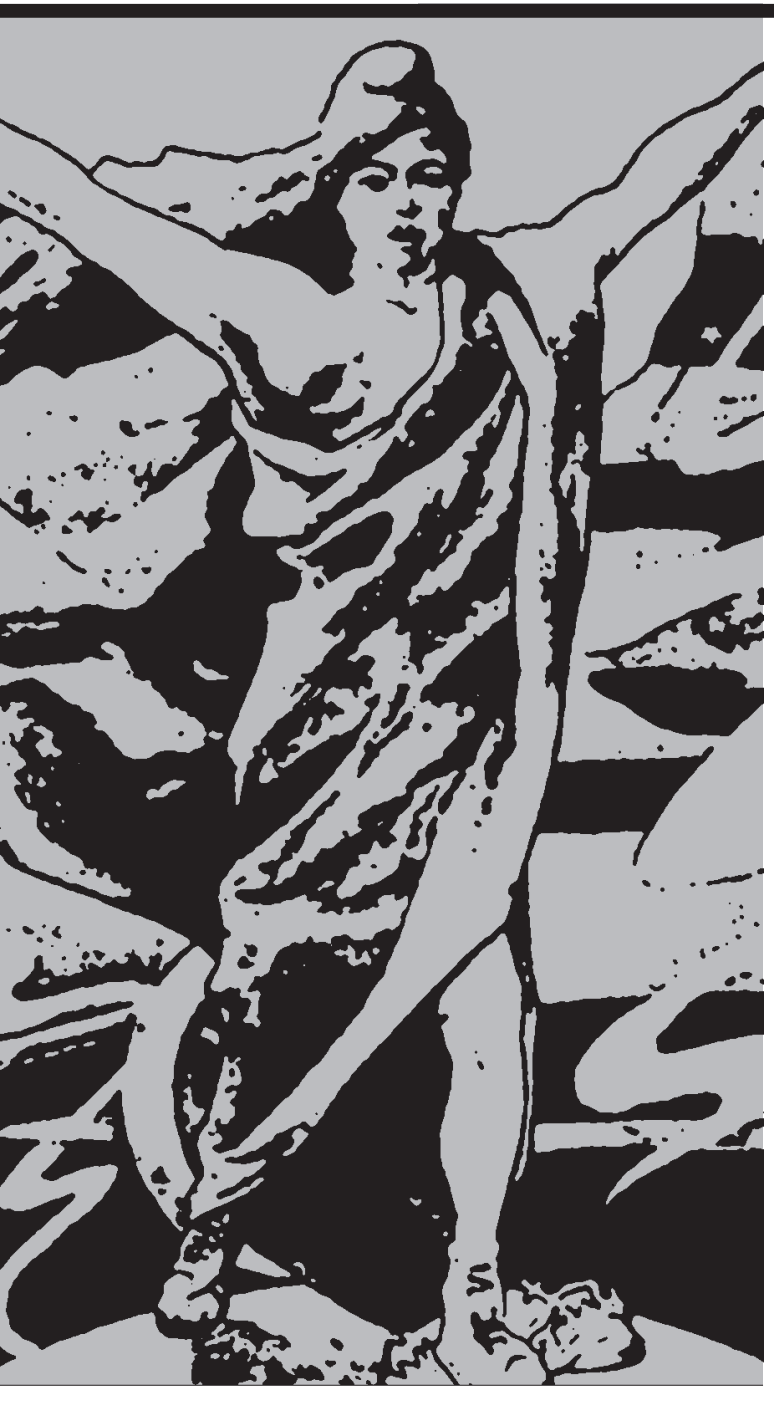

dade insinua duas possíveis interpretações alternativas da relação dos súditos com o soberano e, por extensão, com sua terra natal. Por um lado, um retorno febril, saudosista e rural à imagem da terra como ventre fértil, que gentilmente provê à sua prole as riquezas necessárias à sua prosperidade material. Por outro lado, uma projeção delirante, utópica e machista de uma autoridade soberana exercida de forma gentil pela figura da mãe, em oposição à autoridade firme e inflexível do pai que provê o berço com aquelas riquezas. Em ambas as interpretações, entretanto, um traço comum: a mátria que substitui a pátria despe a república dos traços espartanos do cidadão de armas em punho em defesa de sua terra natal, revestindo-a de uma imagem em que seus ciuma metáfora feminina. Enquanto a associação contemporânea entre o amor à terra natal e a noção de paternidade pode ser atribuída à sobrevivência em tempos modernos dos vínculos que Filmer, entre outros, estabeleciam entre pater potestas (o poder do pai sobre o filho) e o dominium político do soberano sobre o território nacional e seus súditos, a associação heterodoxa entre esse amor e a idéia de materni- dadãos são retratados como pessoas precisando da gentil proteção materna. Despe também a república de seus vínculos com uma concepção da virtude de seus cidadãos etimológica e umbilicalmente ligado a um traço viril de caráter, tal qual encontramos em Maquiavel e tantos outros autores da tradição republicana moderna.

Como nos mostra José Murilo de Carvalho, essa personificação da repú- 


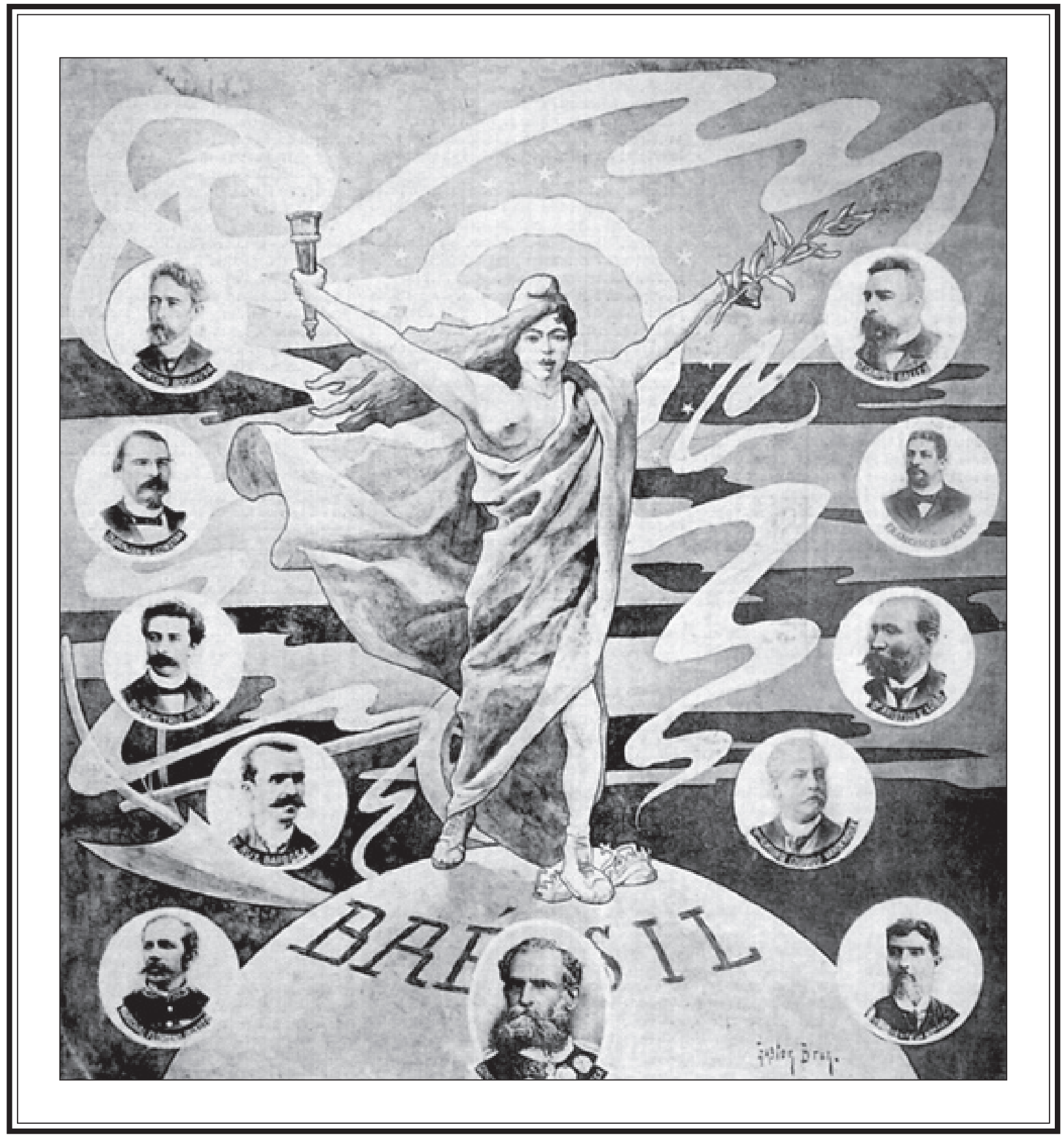

\section{Representação} feminina da república na capa da Revue du Brésil, 1896

VerJosé Murilo Carvalho, AFor mação das Almas, São Paulo Companhia das Letras, 1990 blica em figura feminina já encontrava-se presente no imaginário do século XIX no Brasil (1). Em particular entre os positivistas de inspiração comtiana, essa associação resultava da importação da imagem da mulher enquanto símbolo da república no período após a Revolução de 1789 na França. O contraste com a figura patriarcal dos monarcas até Luís XVI alimentou na França uma imagem feminina da república, revigorada subseqüentemente na segun- da república de 1848. A inspiração para essa feminização da república era romana de origem, mas, no contexto da república romana, a mulher era a liberdade e não a república. É a associação entre república e liberdade que faz convergir as duas imagens. Em nosso contexto nacional, nos lembra Carvalho, a longa tradição marianista do nosso cristianismo forneceu elementos adicionais para a construção da república enquanto mulher. 
Essa tensão lingüístico-simbólica entre a idéia de pátria e a representação da república como mulher tem uma história longa que remete aos tempos clássicos e às maneiras como o republicanismo clássico foi interpretado na Idade Média e na Era Moderna. Neste artigo, pretendo fazer uma genealogia das inúmeras representações da lealdade do cidadão à república no pensamento político ocidental com o objetivo de demonstrar que a problematização histórica desta temática sob a perspectiva da questão de gênero enriquece a nossa compreensão dos limites do patriotismo constitucional defendido por teorias políticas contemporâneas ancoradas no liberalismo democrático, e que a defesa de um forma de republicanismo contemporâneo depende de libertarmos o problema da lealdade do cidadão à república do imaginário patriarcal que sobrevive nesta forma do liberalismo democrático contemporâneo.

Em Aristóteles, a associação entre a questão de gênero e a fundação de repúblicas é explicitada nas analogias entre casa e cidade por ele desenvolvidas tanto na Ética a Nicomano quanto na Política. Já no Primeiro Livro da Política (1259b), Aristóteles afirma que a relação entre esposo e esposa é como a relação entre o politikos e seus concidadãos, simulando a aristocracia como forma de governo, enquanto a relação entre senhor e escravo é semelhante à relação entre o monarca e seus súditos. Na Ética (1161a-b), a analogia é ainda mais detalhada. A philia entre irmãos, por ser entre iguais, constitui a mesma que existe em uma politeia.

No contexto do republicanismo clássico romano, a fundação de repúblicas está intimamente ligada à construção de um mito de origem e, novamente, o problema de gênero está presente na construção desses mitos originários. No livro primeiro da $A b$ Urbe Condita de Tito Lívio, a narrativa da fundação da república romana tem início em uma competição pública entre Collatinus, esposo de Lucretia, e outros homens sobre quem tem a esposa mais virtuosa. Em busca da evidência para resolver a contenda, o grupo sai da casa de Sextus Tarquinius, filho do tirano Tarquinius Superbus, em direção a Roma, onde encontram todas suas esposas divertindo-se luxuriosamente, com exceção de Lucretia, que modestamente vestida trabalhava seu tear. Sextus Tarquinius ficou enamorado com a beleza e castidade de Lucretia, e algumas noites depois invadiu os aposentos da esposa de Collatinus demandando que ela submetesse aos seus desejos de luxúria. As primeiras ameaças de morte não surtiram efeito, mas quando o tirano ameaçou violá-la e depois matála, deitando um escravo morto ao seu lado, configurando desta forma o seu adultério, Lucretia se rendeu. No dia seguinte, ela procurou seu marido, seu pai e Lucius Brutus, um amigo da família. Ela narrou o ocorrido, dizendo que se necessário cometeria suicídio como prova de sua inocência e da veracidade do seu relato. Apesar das tentativas de dissuasão, Lucretia enfiou uma daga em seu peito. Enquanto seu pai e seu marido lamentavam a sua morte, Lucius Brutus puxou a daga do peito de Lucretia e clamou aos demais cidadãos de Roma que se juntassem para expulsar a família do tirano Tarquinius Superbus da cidade. Os homens de Roma se juntaram a Iunus Brutus em busca de vingança e Roma foi liberada, com Lucius Brutus e Collatinus sendo subseqüentemente nomeados conselheiros da primeira república de Roma cerca de 508-7 a.C.

Esse vínculo entre a fundação da república de Roma e o estupro de Lucretia é repetido no De Republica de Cícero (Livro 2:45), e reaparece em Ovídio, Santo Agostinho, Salutati, Boccaccio e em Maquiavel, tanto nos Discorsi quanto em sua peça $A$ Mandrágora. Séculos depois, a história voltou a ser recontada no contexto do Iluminismo francês na peça inacabada de Rousseau, A Morte de Lucrecia e na tragédia Brutus de Voltaire (2). Ou seja, ao longo de uma importante parte da tradição do pensamento político ocidental, a história do estupro de Lucretia manteve um vínculo importante com o tema do republica-
2 Para uma genealogia dos usos da história de Lucretia, recomendo o excelente estudo de Melissa M. Matthes, The Rape of Lucretia and the Founding of Republics (University Park, Penn State Press, 2000 
nismo. A república tem pais fundadores, mas ela tem também suas mulheres, ainda que no caso de Roma fosse a morte de uma mulher que ocasionou a possibilidade da fundação republicana.

A presença de Lucretia na narrativa da fundação da república de Roma e as múltiplas releituras subsequientes apontam para uma interessante relação entre os papéis das metáforas masculinas e femininas no mito de origem que alimenta o republicanismo. Se por um lado são os atos de homens virtuosos como Brutus que desencadeiam o fim da tirania e a fundação da república, a motivação original para esse levante público está num evento da vida privada em que o tema da honra feminina é central. A res publica, portanto, não se funda em oposição ao privado mas em decorrência de uma invasão desse universo por parte do tirano - a corrupção que leva ao fim da tirania é uma violação no âmbito dos valores morais da vida privada. E no centro dessa ordem moral privada está uma mulher, não um chefe de família, cuja honra torna-se motor do processo em questão.

Mas como entender então essa aparente tensão entre um imaginário feminino da idéia de república e um imaginário masculino na idéia de lealdade a ela, expressa no conceito de patriotismo? Para compreender melhor as diversas formas como essa tensão se resolve na tradição do pensamento político, precisamos dar um passo atrás e entender o porquê de chamar de pátria, e não mátria, a representação da entidade republicana em relação à qual os cidadãos devem ser leais.

Se seguirmos a pista aristotélica, a construção da idéia de lealdade à república está vinculada à maneira como se interpretam as relações virtuosas entre os cidadãos que a compõem. E se a amizade (philia) é uma das mais altas das virtudes morais, e tem o papel central designado por Aristóteles na configuração da forma de governo, cabenos compreender melhor como a amizade aparece na tradição do pensamento político como virtude moral, e que papel é atribuído a ela na fundação de repúblicas e na construção de sua imagem (3).
No arcabouço teórico do estagerita, ocorre uma dissociação do vínculo platônico entre o conceito de amor (eros) e o conceito de amizade ( $p$ hilia). Se para Platão o amor era o elemento ativo que levava à amizade, para Aristóteles, o amor é uma paixão enquanto a amizade é uma disposição do caráter (ethos). Aristóteles classifica a amizade em três tipos, dependendo de qual é o objeto da amizade. A forma mais baixa de amizade é aquela baseada no interesse, em que o outro é amigo somente na medida em que a amizade traz benefícios para o sujeito. A forma intermediária de amizade é aquela baseada no prazer, comum entre os jovens, cujo maior problema é ser tão efêmera quanto a primeira, pois, quando acaba o prazer, acaba amizade. A forma mais alta de amizade, a teleia philia, a amizade perfeita, é baseada na similitude dos amigos em suas virtudes. Por serem iguais em virtude, eles desejam o bem do outro com a mesma intensidade com que desejam o seu próprio bem, e enquanto os dois permanecerem virtuosos, a amizade durará.

Para Aristóteles, quando há amizade perfeita entre as partes, isto é, benevolência perfeita, a justiça torna-se uma virtude dispensável. Mas o inverso não é verdadeiro: a justiça enquanto virtude depende da amizade, pois duas pessoas justas precisam também ser amigas para que ajam de forma justa uma com a outra. Esta teleia philia, na medida em que se configura em uma amizade entre iguais que simula a philia que existe entre irmãos na oikos, é a base da timocracia (politeia) para Aristóteles. Esta forma de governo, portanto, a res publica no latim, teria em sua origem um tipo de amizade condizente com aquela que se forma entre irmãos, iguais em idade e posição na oikos. Dela derivaria a politike philia, a amizade política entre concidadãos da politeia que possibilita a concórdia e a paz na comunidade. Nem pátria, nem mátria, portanto; frátria.

No período romano, a discussão mais explícita da relação entre amizade (amicitia) e terra natal (patria) encontra-se em Cícero. Se no universo intelectual aristotélico o tema da virtude (arete) estava vinculado a 
disposições de caráter para agir bem e em direção ao justo, no universo do orador romano, a virtus estava associada à disposição do cidadão em cumprir seus deveres junto ao Estado romano. Assim, enquanto para Aristóteles a amizade perfeita convertida em amizade política estava na base da sociedade justa, para Cícero essa amizade poderia estar em conflito com a justiça e o exercício da virtude. A patria, para Cícero, está acima da amizade, e é imoral e desonroso colocar amicus contra patrium. Se na base de politeia estava uma amizade fraternal constitutiva do ideal de justiça enquanto igualdade, na república romana a amizade era apenas uma das virtudes do cidadão, sendo sua disposição à concórdia, por exemplo, mais importante para a justiça do que a amizade. Enquanto para Aristóteles é a teleia philia que torna possível a justiça (dike), para Cícero é a concórdia que torna possível o surgimento da amicitia perfecta (4). A imagem da liberdade, para os romanos, podia até ser a de uma mulher, mas a res publica era patria, masculina portanto, e sua constituição, em contraste com a interpretação aristotélica, antecede as relações fraternais entre os cidadãos.

No desenvolvimento do cristianismo medieval, observamos o afastamento desse ideal paterno de república na direção de um ideal materno. A amizade é privatizada, tornando-se circunscrita ao problema do monasticismo, e a noção de uma amicitia de caráter mais público migra em um primeiro momento, entre os estóicos, para uma concepção de philantropia, como designação para a idéia de benevolência universal, em que a universalidade de potenciais objetos da benevolência está no centro da virtude do sujeito que a realiza. No tomismo, o tema é deslocado para o conceito de caritas, que não mais designa uma virtude vinculada ao objeto do gesto benevolente mas ao sujeito que a realiza, já que, sob a doutrina do tomismo, a caridade se insere em um contexto soteriológico como uma maneira do cristão contribuir para a sua própria salvação. A amizade, ainda compreendida sob a chave da relação "irmãos em Cristo" constitutiva do discurso do Novo
Testamento, não tem lugar definido nesta concepção de caritas, enquanto o ideal patriárquico de comunidade é substituído pela noção da ecclesia communae, a Igreja, compreendida como figura maternal, que cuida e provê satisfação espiritual para seus fiéis e demonstra compaixão para com aqueles que querem se redimir de seus pecados. É em grande medida o casamento entre essa Igreja-mãe e os novos monarcas-pai que permitirá a construção dos novos estados-nacionais emergentes na Alta Idade Média. O tema da lealdade à república, nesse contexto cristianizado, estava evidentemente deslocado para uma chave maternal, já que a lealdade à Igreja sempre se sobrepunha à lealdade a este ou aquele monarca cristão. Mas o vínculo desse tema ao mito de fundação das repúblicas estava relegado a um segundo plano pelo exercício do desígnio divino na constituição da autoridade secular. A manutenção desse vínculo era restrito, naquele momento da história da Europa, à Itália, onde a Renascença semeava uma nova concepção de lealdade à república que recuperava um imaginário patriarcal.

No "momento maquiaveliano" da filosofia política na península, essa lealdade estava intimamente vinculada a uma idéia de virtude completamente masculinizada, em que restava à Fortuna a condição de mulher, caprichosa e em permanente tensão com o caráter viril do príncipe. Não me parece acidental que a tragédia de Lucretia, tal qual descrita por Tito Lívio, tenha se convertido em comédia na peça A Mandrágora de Maquiavel. Naquela peça do florentino, que era proponente de uma concepção republicana fortemente marcada pela noção masculina de virtú, Lucrezia não é estuprada mas seduzida pelos encantos de seu sedutor, Callimaco; este, perante a possibilidade de fracasso de seu jogo de sedução, é quem cogita se suicidar. Enquanto na narrativa romana é a renúncia feminina de Lucretia a resolução para o enredo da fundação da república, em Maquiavel é a sedução de Lucrezia que resolve o enredo. Tal qual a Fortuna, ela precisa ser seduzida e conquistada, ainda que essa conquista 
nunca seja completa e perfeita. O estupro da versão clássica é convertido em consentimento após a sedução, e o resultado é a fundação de uma república viril, masculi-

\section{A Escola}

de Atenas, de

\section{Rafael}

privada. Comentando a narrativa de Tito Lívio nos Discorsi, Maquiavel reconhece o papel do estupro de Lucretia na fundação da república em Roma, mas interpreta o evento como acidente, e a queda da dinastia tirânica da família da Tarquinius como inevitável resultado da corrupção política da família (5). É em um público já consti-

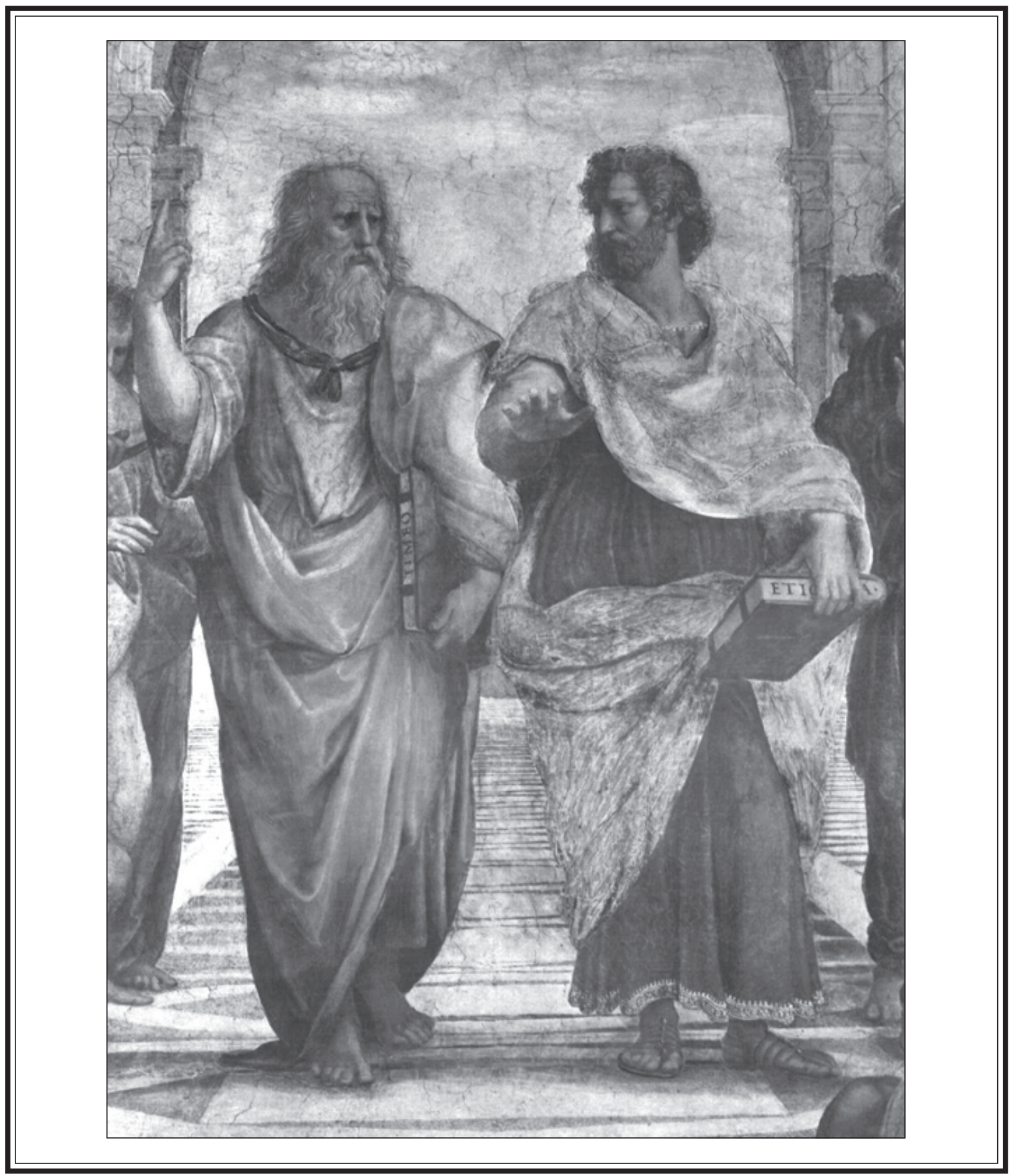


tuído que se dá a fundação da res publica, um público composto de homens virtuosos porque viris e corajosos. Em outras palavras, a república de Maquiavel é uma pátria, e seus cidadãos são leais na medida em que os "pais" dessa república são bons governantes, não importando suas virtudes morais na esfera privada.

Se por um lado essa concepção masculinizada de república em Maquiavel suprime as concepções fraternais e maternais presentes em Aristóteles e no Cristianismo respectivamente, por outro lado ela consolida o caráter público da razões para a lealdade dos cidadãos para com a república, estabelecendo de forma definitiva a divisão daquilo que Kantorowicz denominou de "os dois corpos do Rei”. Mesmo sob o absolutismo dos monarcas europeus dos séculos XVI e XVII esse importante ensinamento da doutrina maquiaveliana será preservado, bem como a imagem masculinizada da lealdade ao soberano absoluto.

$\mathrm{Na}$ mesma corrente do pensamento cristão sobre o tema da amizade - ainda que em direção diametralmente oposta -, Montaigne, em seu ensaio sobre o tema adota uma perspectiva clássica, a busca da teleia philia ou amicitia perfecta, mas a privatiza em um primeiro momento para somente depois lhe dar um caráter público. Escrito com um olhar para seu falecido amigo La Boétie, Montaigne não renuncia a uma discussão propriamente política do tema da amizade e de seu papel na fundação da república, mas sua atenção está voltada primordialmente para uma análise das fontes dessa amizade virtuosa. Ao contrário de Aristóteles e seus seguidores, que viam na semelhança entre as partes uma fonte racional para a construção da teleia philia, Montaigne designa a vontade, e não a razão, como fonte primeira dessa forma de amizade, e a ascensão à virtude daqueles que fazem essa escolha mútua e recíproca é que permite a ambos ascender à virtude. Em Montaigne, como bem aponta Sérgio Cardoso, "só o amigo dá identidade ao amigo, e lhe dá vida; o eu só toma forma na associação" (6). Enquanto em Aristóteles a associação humana era natural, e a leal- dade à pólis derivada das formas de associação e amizade já existentes na casa, para Montaigne a associação é resultado direto da vontade do sujeito, em sua vida privada, de constituir relações de amizade perfeita; virtuosos como resultado desse gesto, tornam-se aptos para a associação e a vida pública. O cidadão, portanto, é acima de tudo um amigo, e sua lealdade para com a república, podemos concluir por inferência, resulta de uma comunhão de vontades, uma comunhão que, em certa medida, prenuncia a concepção de soberania popular que encontraremos mais tarde no conceito de vontade geral elaborado por Rousseau. Independente desse possível vínculo com teorias políticas subseqüentes, podemos afirmar que o republicanismo de Montaigne recupera a imagem da frátria presente originalmente em Aristóteles.

Essa recuperação de um ideal clássico de frátria sugere que o corte entre concepções antigas e modernas na filosofia política não seja tão fácil de ser estabelecido. Benjamin Constant, ao criar o corte entre a liberdade dos antigos e a liberdade dos modernos, incitou inúmeros autores subseqüentes a buscar o momento em que determinados conceitos perdiam sua conotação antiga para adquirir uma nova conotação propriamente moderna. A modernidade inauguraria, portanto, um novo momento da história, uma nova fundação teórica e prática do mundo da política. No entanto, a constante oscilação entre concepções paternais, maternais e fraternais da lealdade cidadã com a república no período moderno não nos permite construir adequadamente um momento de ruptura que teria dado início a uma era de concepções da lealdade à república propriamente designadas de "modernas".

Montesquieu, por exemplo, recupera a imagem patriarcal da lealdade à república presente nos humanistas italianos, apresentando o patriotismo como uma virtude política stricto sensu, em que o interesse público se sobrepõe ao interesse privado. Diferente dos renascentistas, entretanto, Montesquieu atribui a origem dessa virtude a uma pedagogia originária na esfera

\footnotetext{
Ver Discorsi (3.5)

Sérgio Cardoso, "Paixão da lgualdade, Paixão da Liberdade: a Amizade em Monta igne", in Adauto Novaes lorg. Os Sentidos da Paixão São Paulo, Funarte/Companhia da Letras, 1999, p. 192.
} 
privada, na educação que os pais (homens) dão a seus filhos no ambiente doméstico (7). Em Rousseau, por outro lado, enquanto a imagem masculina da lealdade permanece presente, sua origem não se encontra da paideia do filho no ambiente do lar, mas na instituição de uma religião civil e pública, centrada na liberdade, que permitisse ao cidadão identificar-se permanentemente com a vontade geral expressa pelo soberano. No lugar do vínculo entre amizade perfeita e lealdade à república encontrada em Aristóteles, Rousseau revigora uma concepção mais espartana de patriotismo já encontrada em Cícero em sua discussão da relação entre virtus e cidadania (8).

Com a Revolução Francesa e seu mote liberté, egalité, fraternité, testemunhamos uma reintrodução do tema fraternal no seio da discussão sobre a natureza da relação entre os cidadãos e a república. Em oposição a philantropia dos estóicos ou a caritas da Igreja tridentina, essa concepção de amor fraterno universalizado que estava explicitada no mote daquela revolução era supostamente imbuída de um sentido secularizado de amor ao próximo. Entretanto, o conflito entre universalismo de valores e caráter politicamente circunscrito do processo de ruptura em curso tornava esse ideal, expresso em inúmeras declarações de direitos do homem daquele período, secundário em relação aos dois outros termos que compunham a tríade do mote. O conflito entre o particularismo político da ruptura revolucionária e o sentido universal do conceito de fraternidade ficou explicitado em inúmeros contextos em que o termo foi substituído na montagem da tríade. Em diversos contextos da Revolução Francesa, falava-se em liberté, egalité ou la morte, por exemplo; e vale lembrar que, mesmo quando era explicitamente evocada, a idéia de fraternidade não era extensiva nem

7 Montesquieu, O Espírito das Leis, livro 4, cap. 5 .

8 J.J. Rousseau, 0 Contrato Social, livro 3, cap. 15 e livro 4 cap. 8 .

9 Para uma síntese dessa "guinada clotildiana" do pensamento de Comte, ver: Carvalho, op cit., pp. 129-32 usado pela primeira vez, em parte por causa da crescente influência da maçonaria sobre o republicanismo francês. Tal qual em Rousseau, no contex to daquela revolução, o problema do patriotismo estava mais fortemente vinculado ao tema da liberdade.

O reaparecimento do termo "fraternidade" depois de 1848 na França também estava vinculado à influência do positivismo. Comte, após o seu encontro com Clotilde de Vaux em 1844, ao qual ele atribuiu sua "regeneração moral", abandona o racionalismo que até então imprimia o tom de sua ciência positiva, em prol de uma religião da humanidade, cívica e laica, que resgatava importantes elementos da concepção rousseuaniana de religião civil elaborados em O Contrato Social. Comte, após a guinada "clotildiana" de seu pensamento, passa a valorizar uma concepção de fraternidade centrada no altruísmo enquanto substituto funcional da caritas do catolicismo. Esse amor fraternal em relação à humanidade, no pensamento comtiano, era a última etapa hierárquica da evolução das afetividades solidárias humanas, que se iniciava no âmbito da família, passava pela pátria e culminava na humanidade como um todo (9).

No positivismo comtiano, o momento patriótico, de amor pela confraria dos cidadãos, estava ainda impresso de um ideal masculino, uma vez que o objeto desse amor era a pátria. O que muda, entretanto, é a forma desse amor; nem amor maternal pela Igreja-mãe, nem amor paternal pelo monarca-pai, nem amor filial pela repúblicamulher. $\mathrm{O}$ amor do cidadão pela pátria era um amor que deveria simular a forma mais alta de altruísmo, o amor pela humanidade, inúmeras vezes representada na arte positivista do século XIX pela imagem de Clotilde. Esse amor, portanto, simulava o amor pela mulher amada, tal qual a philia entre esposo e esposa descrita por Aristóteles, e que dava origem à idéia do governo aristocrático. Parece-me que o encontro de Stuart Mill com a filosofia de Comte o levou a propor um conceito muito similar de fraternidade universal, e que sua solução para o problema do governo da república, 
por conseguinte, também era orientada por um ideal aristocrático, expresso na concepção de governo representativo. Em suma, a idéia laica de fraternidade inaugurada pela Revolução Francesa e elaborada em Comte e Stuart Mill não alterou de forma significativa o debate conceitual sobre o tema da lealdade à república, já que para ambos o patriotismo estava alicerçado na particularização de um tipo de amizade em relação à humanidade como um todo cujo modelo era amizade entre esposo e esposa.

Bem mais importante na transformação das concepções de patriotismo no século XIX foi a incorporação do conceito de nacionalismo no discurso político daquele período (10). O advento de uma concepção romântica de nação representou uma forma muito particular de interpretar o patriotismo, uma vez que deslocava o problema da lealdade dos cidadãos para com a república do eixo da liberdade e dos laços filiais, paternais ou maternais que os cidadãos mantinham com o corpo político, para o eixo da lealdade a uma mesma nação dos membros pertencentes a ela. Vale lembrar que esse conceito de nação desvincula o conceito do problema da formação dos Estados modernos. Na definição de Gellner, o que define a nação é o compartilhamento de uma cultura, isto é, "um sistema de idéias, signos, associações e formas de comportamento e comunicação" (11). Ou seja, é possível conceber Estados compostos de diversas nações, bem como nações fragmentadas por fronteiras territoriais entre Estados.

O nacionalismo, dessa forma, faz referência à lealdade dos membros de um povo à cultura e às tradições de uma nação, e no contexto moderno de sua introdução no discurso político do século XIX, remetia também à idéia da autodeterminação dos povos na formação de Estados, e de que os territórios ocupados por uma determinada nação não fossem cortados por unidades político-territoriais. Podemos dizer então que o nacionalismo é uma forma de patriotismo que opera em uma dimensão simbólica, como mecanismo de legitimação política de um conjunto de valores com- partilhados por determinada comunidade concreta que se imagina como comunidade na medida em que seus membros, na maior parte das vezes, não se conhecem todos mutuamente; o que ancora o conceito de nação é um sentido de comunidade imaginada, construída a partir de tradições (em especial, uma língua) e uma história (12). O nacionalismo se manifesta na participação em ritos, na arte, nos festivais da comunidade; em termos mais gerais, em uma lealdade à cultura da nação. Enquanto forma particular de lealdade a uma vida pública compartilhada, portanto, o nacionalismo, na medida em que nação e república nem sempre coincidem e convergem em uma mesma organização políticoterritorial (um Estado), realiza uma desterritorialização da idéia de lealdade à república.

Curioso notar como autores que buscaram alguma forma universalista de compreensão do problema da lealdade à república que fugisse do nacionalismo em sua vertente romântica foram obrigados a abandonar, ou pelo menos relativizar radicalmente, a própria idéia de nação. Esse é o caso, por exemplo, de Kant, cuja concepção de paz perpétua constituída da perspectiva de um cidadão cosmopolita não comporta nenhuma forma de patriotismo que não se estabeleça em relação à humanidade como um todo, replicando o ideal de fraternidade secular posto em segundo plano no imaginário da Revolução Francesa e recuperado subseqüentemente por Comte e Stuart Mill. Mais distantes do universalismo político kantiano, entretanto, esses autores podiam falar em uma fraternidade universal e laica sem derivar as implicações políticas com relação ao problema da nação.

Mas como a questão de gênero aparece na versão desterritorializada da lealdade à república que aparece com o nacionalismo? Os usos das expressões Vaterland e Mutterland no alemão são exemplos interessantes do que ocorre com o patriotismo sob a égide do nacionalismo. Enquanto no inglês os termos fatherland e motherland sempre foram utilizados de forma inter-
10 Sobre o impacto do conceito de nacionalismo sobre o patriotismo no século XIX, ver o exceente ensaio "Patriotismo", de Mary G. Dietz (in T. Ball, J. Farr e R. L. Hanson (orgs.) Political Innovation and Conceptual Change Cambridge, Cambridge University Press, 19891.

$11 \mathrm{E}$. Gellner, Nations and Nationalism, Ithaca, NY, Cornell Univ. Press, 1983, p. 7

12B. Anderson, Imagined Communities, 2a edição, Lon dres, Verso, 1991 
cambiável, no alemão os termos correspondentes fazem referência a campos semânticos distintos. $\mathrm{O}$ adjetivo vaterländlich é utilizado no alemão desde o século XVIII para referir-se à idéia de lealdade à república, sendo o substantivo neutro Vaterland um termo para descrever "a terra de meu pai"; ou seja, o adjetivo pode ser traduzido como patriotismo, construído a partir de uma metáfora masculina e paternal. O termo Mutterland, por sua vez, é utilizado no alemão para designar o "país-mãe" em um contexto imperialista, em oposição às colônias que esse país possui. Nesse caso, percebe-se que o termo feminino e maternal adquire um sentido mais próximo à idéia romântica de nação, já que pertencem à Mutterland somente aqueles que pertencem ao povo no centro do império. O nacionalismo, portanto, como forma específica da idéia de patriotismo, comporta ambigüidades que fazem o termo oscilar entre metáforas masculinas e femininas, sempre, entretanto, vinculadas ao tipo de amor/amizade existente entre pais e filhos. Não por acaso, quando ocorre a coincidência entre república e nação em uma mesma unidade político-territorial, cria-se a oportunidade lingüística para ambigüidades do tipo encontrado na última linha do nosso hino nacional: temos uma "pátria-mãe", da qual somos todos filhos. Em todos os casos, porém, o nacionalismo realiza um deslocamento completo do ideal aristotélico de frátria que persistia em autores como Montaigne.

Essa dialética tensa e paradoxal entre patriotismo e nacionalismo está impressa na trajetória dos Estados-nação no século $\mathrm{XX}$, tanto nas democracias representativas quanto nos regimes autoritários e totalitários. Aliás, muitas nas inúmeras guerras desse século, talvez até a maioria delas, tiveram raízes em descompassos entre pátria e nação: pátrias compostas de diversas nações em conflito, nações ambicionando a condição de Mutterland vis-à-vis outras pátrias através de conquista, nações cindidas por duas ou mais pátrias, nações buscando libertar-se de impérios, e assim por diante. De toda forma, o nacionalismo, misturando metáforas maternais e paternais, torna-se o paradigma do patriotismo durante todo o século XX. É somente no final deste, com o suposto enfraquecimento dos Estados-nação em relação a uma ordem econômica internacionalizada, que vamos testemunhar uma nova mudança conceitual na formulação da lealdade dos cidadãos à república.

\section{$\bullet \bullet$}

Nas principais teorias democráticas do século XX, a atribuição da soberania ao povo de uma república implicava uma solução via bifurcação conceitual para os paradoxos da "pátria-mãe". O ideal democrático-representativo busca uma reconciliação entre a idéia de cidadão leal a sua nação, porque compartilha valores com ela e goza das prerrogativas da inclusão na sua ordem jurídica, e de cidadão leal à república, porque sua escolha soberana de seus representantes tem como contrapartida seu civismo. Bifurca-se, portanto, a lealdade do cidadão, e funda-se um ideal paternal e outro maternal da forma dessa lealdade. $\mathrm{O}$ modelo de lealdade à república é apresentado como relação paternal, constituída de deveres cívicos de lealdade ao soberano, e o modelo de lealdade à nação é representado como relação maternal, constituída de direitos de compartilhamento nos frutos da cultura e da riqueza do Estado-nação.

A conversão desse ideal democráticorepresentativo em ordem constitucional implica uma arquitetura de distribuição de direitos e deveres que, no contexto liberal em que surgiu esse ideal, concede prioridade aos direitos fundamentais, tratados às vezes como invioláveis e anteriores mesmo ao estabelecimento da ordem, surge dessa maneira também como resultado da antecedência histórica e lógica da unidade político-territorial que trará ao concreto a idéia de povo-nação. Antes de se tornar república, portanto, com cidadãos dotados de deveres cívicos, toda ordem constitucional-democrática é expressa como nação, com cidadãos com direitos de pertencimento e participação na cultura e riqueza 
que são anteriores aos deveres que assumirão perante a república.

A tentativa de superação dessa matriz liberal e de resolver de maneira distinta o problema da anterioridade dos direitos sobre os deveres que ela implica encontra uma de suas melhores argüições na teoria política de Jürgen Habermas, e resulta de seu esforço nesse sentido uma nova concepção de lealdade à república a qual ele denominou de "patriotismo constitucional". De acordo com Habermas, o caráter plural e complexo do ponto de vista cultural das sociedades contemporâneas requer uma nova concepção de patriotismo que não só restabeleça seus laços com a idéia de uma ordem jurídico-constitucional territorialmente delimitada, mas que também seja capaz de libertá-la da agenda nacionalista que substitui e desloca o tema da pátria para o plano da comunidade nacional. Em um contexto em que essas comunidades são multiculturais, ou seja, compostas de diversas perspectivas étnico-nacionais, a solução comunitarista para o problema do patriotismo, na visão de Habermas, retira da idéia de lealdade à república como componente da cidadania sua capacidade de lidar com a diversidade cultural que caracteriza a maior parte das unidades político-territoriais contemporâneas. Uma cidadania democrática, nesse sentido, requereria libertar o conceito de patriotismo da perspectiva particularista e paroquial que uma concepção comunitarista carrega.

Nos moldes do universalismo kantiano, o "patriotismo constitucional" de Habermas aponta na direção de uma cidadania mundial, da qual eventos como a Guerra do Vietnã, as transformações políticas no Leste Europeu e a Guerra do Golfo seriam um prenúncio, já que se constituíram, no plano da comunicação política, como eventos políticos mundiais referidos a uma sociedade civil internacional emergente. Nessa versão do patriotismo, a lealdade do cidadão à república não se dá nem no plano territorial, nem no plano da comunidade nacional, mas sim no plano dos próprios procedimentos democráticos de formação da soberania popular; é a esses procedi- mentos que o cidadão deve, em última instância, uma lealdade necessária (13). Podemos dizer, portanto, que se o nacionalismo realizou uma desterritorialização do conceito de patriotismo, esse kantianismo renovado da teoria democrática habermasiana realiza uma "descomunitarização" daquele conceito.

Do ponto de vista da questão de gênero, na medida em que o patriotismo constitucional habermasiano estabelece uma lealdade a procedimentos que não pode ser exclusivamente voluntária, mas resultado da própria força imperativa da racionalidade comunicativa, deparamo-nos com uma concepção que retém os traços do patriotismo sob a forma específica do nacionalismo, isto é, seja como modelo paternal ou maternal, a lealdade do cidadão a esses procedimentos é uma imposição da razão. Em contraste ao nacionalismo, porém, cuja concepção de lealdade em um contexto liberal implicava a antecedência do momento maternal dos direitos em relação ao momento paternal dos deveres, Habermas propõe a simultaneidade da constituição desses dois momentos na produção de uma ordem liberal-republicana.

O problema dessa descomunitarização do conceito de patriotismo, entretanto, é análogo ao que Kant enfrentou ao tentar desenvolver um ponto de vista cosmopolita para a organização da política. Ou concebemos um mundo completamente desprovido de fronteiras nacionais, ou precisamos, em alguma medida pelo menos, lidar com a política na chave amigo/inimigo, tal qual Carl Schmitt propunha. Em outras palavras, por mais otimistas que sejamos quanto a organizações supranacionais tais como a União Européia, não podemos escapar da existência concreta de nações e dos conflitos (reais e potenciais) entre elas. Dessa perspectiva, somos forçados a introduzir algum grau de paroquialismo na interpretação da lealdade do cidadão à república, e não podemos portanto constituir o patriotismo do ponto de vista universal que Habermas almeja. O patriotismo, como nos lembra Hannah Arendt, é e sempre será uma "responsabilidade por
13 J. Habermas, Between Facts and Norms, Cambridge, MIT Press, 1996, Apêndice 2 
uma comunidade comum e limitada" (14). Assim sendo, o patriotismo constitucional de Habermas só pode operar como horizonte normativo para comunidades nacionais em que a democracia procedimental por ele proposta, como valor moral compartilhado, esteja sedimentada. Ou seja, a identificação dos concidadãos que pertencem à república em relação à qual manifestam lealdade sempre antecede a expressão dessa lealdade. Mais uma vez, o tema da amizade, compreendida na chave aristotélica na qual a discutimos na primeira parte deste artigo, precisa ser reintroduzido.

Como nos mostra Charles Taylor, o conceito de patriotismo ainda é um conceito que se coloca em um plano intermediário entre a amizade como sentimento familístico de lealdade para com aqueles que fazem parte do meu círculo de interações cotidianas e a dedicação altruística ao outro universalizado expresso no conceito de fraternidade laica dos positivistas do século XIX. Em outras palavras, o patriotismo deve permanecer, por imposição do campo semântico que ocupa e das realidades concretas com que pretende lidar, entre o universalismo da fraternidade e o particularismo da amizade (15). Esse campo intermediário, seja no republicanismo clássico ou em um republicanismo adaptado ao contexto da política contemporânea, requer uma concepção de bem comum, compartilhado e valorado pelos cidadãos, que se traduz, portanto, em uma lealdade à república que a provê e a reproduz. Esse bem comum pode ser entendido de uma perspectiva mais ampla, em que ele coincide com o bem de cada um e converte-se dessa forma em um bem de todos, ou, de uma perspectiva mais estreita, remetendo aos planos de vida (life plans) convergentes, compartilhados e valorados pelos cidadãos.

O tipo de patriotismo constitucional Totalitarianism, San Diego, Harvest/HBJ Pubs, 1951, p. 232.

15 C. Taylor, "Cross-Purposes: The Liberal-Communitarian Deba te", in N. L. Rosenblum (org.) Liberalism and the Moral Life, Cambridge, Harvard Univ. Press, 1989, p. 166

16 Idem, ibidem, p. 172 que essa forma mais ampla de interpretar o bem comum não é capaz de entender e explicar o movimento inverso, qual seja, aqueles momentos em que os cidadãos revoltam-se contra a república vis-à-vis o que consideram ser alguma violação contra o bem comum. Na chave liberal da interpretação desse bem comum como bem individual coincidente com o bem do outros, tal revolta contra a república precisaria ser necessariamente interpretada como resposta a uma violação dos interesses privados do cidadão; entretanto, como mostra Taylor, essa revolta raramente resulta de cálculos de curto ou longo prazo por parte dos cidadãos, e portanto não se situa no contínuo egoísmo-altruísmo da esfera dos interesses. Pelo contrário, o que geralmente move essa revolta é alguma espécie de identificação patriótica com uma forma de vida compartilhada que está sendo violada. Mesmo sob a chave liberal, portanto, necessitamos de uma concepção do bem comum que abarque elementos ético-morais substantivos mais robustos do que simplesmente o Estado de Direito e o patriotismo constitucional que pode ser construído em relação a ele. Em outras palavras, o liberalismo requer a dimensão motivacional do patriotismo, e é esta proposição básica conectando liberdade e patriotismo que Taylor chama da “tese republicanista" contemporânea (16).

É precisamente porque o patriotismo é menor que um conjunto de valores compartilhados em uma ordem comunitarista, mas maior que o minimalismo dos universalismos deontológicos de inspiração kantiana, que combinam uma concepção paternal de deveres e outra maternal de direitos no que tange à lealdade do cidadão à república, que se torna necessário conceber o patriotismo como um amor ao particular de outra natureza, entre a amizade e a fraternidade: uma forma de paroquialismo moral que não se define a partir das relações de direitos e deveres que o cidadão tem com a república, mas que antecede essas relações através daquilo que Richard Dagger denomina de "laços de reciprocidade entre os cidadãos". Na defesa desse 
paroquialismo moral, a lealdade à república está acima de quaisquer universais porque compartilho com o meu concidadão a construção de laços de reciprocidade que definem os termos do nosso respeito mútuo na esfera pública democrática (17).

Retornamos, portanto, através desse paroquialismo moral qualificado do republicanismo contemporâneo de autores como Taylor e Dagger, a uma concepção fraternal de patriotismo - uma frátria como a politeia aristotélica e a república cética de Montaigne - centrada na amizade pública entre cidadãos iguais. Não precisamos da concepção forte de bem comum dos comunitaristas, centrada em valores e tradições morais compartilhadas para constituir esse ponto de vista republicano; basta a ele uma concepção de bem comum centrada nos valores ético-políticos que emergem dos laços de reciprocidade que estabelecemos com nossos concidadãos. Mas não nos basta a concepção fraca de bem comum dos liberais; nossa lealdade à república é independente e anterior ao que ela nos concede na forma de bens ou direitos individuais que desejamos ter.

Mas resta uma questão: o que nos protege contra a possibilidade de o paroquialismo moral do republicanismo converter-se em comunitarismo e até mesmo fundamentalismo? A solução dos positivistas do século XIX era uma concepção secularizada de fraternidade; a dos liberais do século XX era uma concepção universalizada de direitos humanos. Pode esse republicanismo contemporâneo e seu paroquialismo moral incorporar uma dessas soluções? Creio que a argumentação apresentada até aqui justifique uma resposta negativa. Precisamos de uma alternativa conceitual que nos permita exprimir uma amizade universal pela humanidade e que nos liberte, dessa maneira, das soluções sempre potencialmente belicosas nas quais esse paroquialismo sempre corre o risco de cair sob a chave schmittiana "amigo/inimigo".

Este artigo não é o lugar apropriado para uma análise mais detalhada dessa questão. Mas fica registrada aqui pelo menos uma possível solução. A idéia de fraternidade é limitada seja pelo localismo ou pelo universalismo exacerbado que ela carrega. Por um lado, o termo hoje encontra-se demasiadamente vinculado à idéia de pequenos grupos com causas precisas, até mesmo irmandades, como no caso das fraternities universitárias norte-americanas, para exprimir um ideal universal. Por outro, quando expressa nos termos do positivismo do século XIX, ela remete a uma lealdade, a uma humanidade que é uma abstração, impessoal, e que não difere entre povos, nações e repúblicas com as quais, por inúmeros motivos de ordem ética ou moral, não desejamos incluir no âmbito dessa amizade pela humanidade no concreto, enquanto conjunto de seres humanos com os quais compartilhamos um conjunto mínimo de valores morais como, por exemplo, a idéia de direitos humanos fundamentais.

Para melhor compreender a natureza desse tipo de relação do paroquialismo moral do republicanismo com uma idéia de amizade mais universal, podemos tomar como ponto de partida a interessante (e certamente intencionada) substituição que a Constituição da União Européia faz do clássico lema liberté, egalité et fraternité da Revolução Francesa pelo lema "liberdade, igualdade e solidariedade". A idéia de solidariedade, em oposição à idéia de fraternidade, remete à vida em sociedade em termos de dependências concretas e reais entre repúblicas que são solidárias porque necessitam umas das outras para a sua própria reprodução e sobrevivência como unidades político-territoriais. Nesse sentido, o ideal que estamos buscando nesta nossa tentativa de superar os vieses de gênero no tratamento do problema da lealdade à república no pensamento político moderno é o de uma frátria solidária.

Em suma, e parodiando a epígrafe deste artigo, retirada da canção "Língua” de Caetano Veloso, nossa república é nossa pátria. Mas nós não temos uma pátria espartana; temos uma mátria liberal. E se queremos uma frátria solidária, é necessário que redefinamos os termos com que exprimimos e articulamos nosso ideal de lealdade à república.

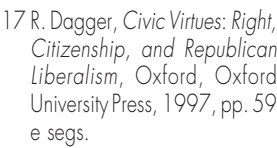

Citizenship and Republican e segs. 